\author{
D. Bulanin $^{1 *}$, Ye.A. Marchenko ${ }^{2}$, G.K. Abitayeva ${ }^{1}$, L. Vangelista $^{1}$ \\ ${ }^{I}$ Nazarbayev University School of Medicine, Biomedical Sciences Department, Nur-Sultan, Kazakhstan; \\ ${ }^{2}$ Republican Diagnostic Center, Nur-Sultan, Kazakhstan \\ *Corresponding author: dbulanin@nu.edu.kz
}

\title{
Genetic organization and cellular specificity of $S$. aureus leukocidins
}

\begin{abstract}
Currently, infections produced by the gram-positive bacteria $S$. aureus represent a significant healthcare burden throughout the world. This is attributed to the ability of this bacterium to develop antibiotic resistance and efficiently evade human immune response. Therefore, research effort of many scientific laboratories worldwide is directed toward characterization of the genetic organization and molecular mechanisms responsible for $S$. aureus pathogenesis. This report is aimed to describe the growing body of evidence related to our understanding of the genetic organization and molecular interactions of the $S$. aureus leukocidins with the human cells that play an important role in bacterial pathogenesis, and represent a significant healthcare burden. Understanding of the genetic organization linked with additional mechanisms responsible for the realization of toxic potential, can help us to develop a better personalized approach for therapy against $S$. aureus infections. Thus, improved understanding of the molecular interactions between $S$. aureus leucocidins, and cell surface receptors may lead to the development of the alternative anti-microbial agents, that either independently or in combination with the current antibiotic treatment regimens will be used as an effective treatment strategy in clinic.
\end{abstract}

Keywords: Staphylococcus aureus, genetic organization, leukocidins, bacterial infection, toxins, isolates.

\section{Introduction}

Staphylococcus aureus (S. aureus) is a gram positive cocci-shaped bacterium responsible for one of the most predominant bacterial infections in the world. The range of diseases produced by $S$. aureus encompasses the infection of many human tissues and organs, including the skin, nares, bones, joints, muscle, heart and lungs. Currently, the standard treatment for these infections includes the use of antibiotics.

Historically, S. aureus infection was sensitive to many common antibiotics. In the early $1940^{\text {th }}$, ampicillin was the antibiotic of choice, being highly effective against the infection. Later, penicillinase — producing strains emerged, which manifested in the first widespread distribution of antibiotic-resistant bacteria worldwide, due to the uncontrolled use of penicillin [1]. The spread of penicillin-resistant $S$. aureus manifested in the pandemic of the 1950s and early 1960s. This pandemic was attributed to a single strain of $S$. aureus, known as phage-type 80/81 [2]. The pandemic associated with this strain was reported to decline in 1959, after introducing the methicillin antibiotic as a primary choice for treatment of the infection. Not for long, as the emergence of methicillin-resistant strains (MRSA) in hospital settings was reported in 1964 [3].

The statistics reflecting S. aureus infection in Kazakhstan is scarce or not available at all. However, if we consider the statistics from the US, S. aureus has the highest rate of hospital-associated infections, with increasing prevalence attributed to MRSA strains as compared to other bacterial pathogens $[4,5]$. The mortality rate of MRSA-associated infections in US is approximately $20 \%$. It is the highest among the death rate attributed to a single infectious agent, and surpasses the death rate associated with HIV/AIDS [6, 7].

The next important step in the historical chain of events related to $S$. aureus infection evolution was the reporting of the first case of community-associated MRSA (CA-MRSA) infections in Australia in 1990 [8]. Since then, CA-MRSA underwent a massive spread throughout the world [8]. This spread of infection represents a rather unusual event, since prior identified $S$. aureus infections in the population were exclusively attributed to the methicillin-sensitive strains [9]. In conjunction with the increasing prevalence of CAMRSA, these strains can cause fatal disease, and affect virtually any tissue. However, approximately $90 \%$ of the cases constitute infections of skin and soft tissue [10]. This has become a significant burden for the healthcare system and human health and requires the development of new anti-microbial agents capable to effectively combat this infection.

According to the Center for Disease Control (CDC), the transmission of S. aureus is accomplished through five major factors, which are abbreviated as «Five C's» [11]: the Contact with the infected person; the lack of Cleanliness in the surrounding environment; Compromised skin integrity; Contaminated objects 
and surfaces; and the Crowded living conditions. Therefore, individuals of young age, low socioeconomic status, drug users and ethnic minorities are predicted to be the most susceptible groups for CA-MRSA infection in the US [12].

The standard methods for isolation of $S$. aureus include the culturing of the pathogen from blood, body fluids or the focal sites of infection. Antibiotic sensitivity is determined by a standard disc diffusion essay, or an automated method. Therefore, the identification of CA-MRSA strains is fairly simple and efficient. This efficiency unfortunately does not translate into an effective treatment, since the prevalence of the CA-MRSA is increasing throughout the world every year. The current treatment usually includes second-line antibiotics such as trimethoprim-sulfamethoxazole, clindamycin and vancomycin [13]. However, the use of vancomycin is often associated with recurrent bacteremia during therapy, high rates of clinical failure, nephrotoxicity and increasing prevalence of non-susceptible strains [13-16]. According to increasing evidence, the majority of antibiotic-resistant genes and genes encoding virulence factors reside on mobile genetic elements, such as plasmids, transposons and prophages [17]. In S. aureus, the repertoire of these factors has been studied extensively, due to the increasing urge for the identification of the new treatment strategies. Virulence factors include cell surface bound and secreted factors that may inhibit the complement and antimicrobial peptides, promote colonization, induce or suppress leukocyte recruitment or induce leukocyte lysis [18].

Human neutrophils are the primary line of defense capable to phagocytose $S$. aureus bacteria. However, a significant number of bacteria phagocytosed by neutrophils remain viable and either trigger new infections or kill the neutrophils by lysing them [19]). Recent data demonstrates that CA-MRSA strains are most efficient in evading neutrophil killing, and they do so by inducing the neutrophil lysis faster than any other health care-associated strain [20]. This is a strong indication that some of the CA-MRSA strains are more virulent than any other strain of $S$. aureus and represents an example of successful evolutionary adaptation of $S$. aureus to the human host defense system. This adaptation is likely the reflection of an enhanced repertoire of virulence factors located in the bacterial genome as well as on extra-chromosomal elements.

The entire genome of $S$. aureus can be subdivided into the core genome, comprising approximately $75 \%$ of the genes, and the auxiliary genome ( $25 \%$ of the genes). The core genome is largely represented by housekeeping genes, while the auxiliary genome consists of mobile genetic elements(MGE), including bacteriophages, chromosomal cassettes, pathogenicity islands, transposons, and genomic islands [21]. Each bacterial strain may carry a unique variety of mobile genetic elements [22, 23]. This variability is often the result of horizontal gene transfer of mobile genetic elements between bacteria and have important clinical implications (e.g., different antibiotic resistance and/or various degree of pathogenicity) [21, 24]. The entire repertoire of $S$. aureus virulence factors is described in details in a large body of scientific literature. In this review we focused on the group of secreted pore-forming toxins called leukocidins that $S$. aureus uses to destroy immune cells and evade the immune system.

\section{S. aureus pore-forming leukocidins in human pathogenesis}

As mentioned above, $S$. aureus possesses a multitude of virulence factors used by the pathogen to evade the human immune system. This repertoire may be subdivided into three main groups. The first group includes cytotoxins such as hemolysins, cytolytic peptides and leukocidins. The second group includes immunomodulatory proteins such as superantigens, superantigen-like proteins and complement-inhibitory proteins. The third group includes proteases and factors involved in evasion of immune cell recognition and killing [25-29]. Allthese three groups of factors make S. aureus virtually «bulletproof» by allowing it to combat human innate and adaptive immune systems (see below), and represent a significant challenge in the development of new effective antimicrobial agents and vaccines against the pathogen [30-32]. Pore-forming leukocidins are the main focus of this review.

\section{Pore forming leukocidins and their mechanism of action}

Six pore-forming leukocidins (also called leukotoxins) have been identified to date. They acquired their names based on their ability to destroy leukocytes such as, phagocytes, natural killer cells, dendritic cells and $\mathrm{T}$ lymphocytes, and therefore affect innate and adaptive immunity [29]. Leukocidins include: HlgAB, HlgCB, LukAB/HG, Panton-Valentine leukocidin (PVL) consisting of LukS-PV and LukF-PV subunits, LukED and LukMF. HlgAB, HlgCB and LukAB/HG are produced by all strains of $S$. aureus. The most virulent strains often produce two additional leukocidins, PVL and LukED. LukMF has been found in isolates from ruminants and other mammals but not in strains infecting humans [29]. Pore formation depends on the production of bi-component, oligomeric pores, consisting of two separate polypeptides known as $\mathrm{S}$ and $\mathrm{F}$ 
subunits [33, 28[. There are six S subunits (HlgA, HlgC, LukA, LukS-PV, LukE and LukM) and four complementary F subunits (HlgB, LukB, LukF-PV and LukD), resulting in the six different combinations of bicomponent leukocidins described above [28].

One of the first suggestions that $S$. aureus toxins such as PVL may produce pores on the surface of human leukocyte membranes have been proposed by Rogolsky et al., in 1979 [34]. Subsequently, a significant number of experimental data accumulated and supported the notion that pore formation is the major mechanism underlining cell death induced by $S$. aureus leukocidins [29].

According to a proposed model [29], S. aureus secretes water soluble toxins as monomeric S and F subunits. In the majority of cases the $\mathrm{S}$ subunit (and only in some cases the F subunit) recognizes the target cell surface by binding to either specific receptors or lipids. Once bound to the cell surface, the S subunit recruits its partner F subunit, followed by subunit oligomerization leading to the octameric pre-pore conformation, consisting of four $\mathrm{S}$ and four $\mathrm{F}$ subunits. Next, the pre-pore leukotoxin octamer undergoes a dramatic conformational change with the insertion of the stem domain of both subunits into the plasma membrane of target cells, leading to the formation of a functional pore. Toxin pores on the plasma membrane lead to osmotic balance disruption (osmotic shock), ultimately causing cell lysis and death [35-37,29]. Generally, eukaryotic cell death may have a dual nature either necrotic or apoptotic. Necrotic cell death is usually due to physical or chemical cell injury and it is considered to be a passive process. Conversely, apoptosis is considered to be an active process induced by extracellular stimulior genetic programming regulating various intracellularsignals or both. Taking this information together, it is plausible to suggest that pore formation produces the necrotic like damage to the cell surface and eventually cell death, likely, without activation of apoptotic signaling cascade. However, the latter statement is yet to be confirmed. Depending on the leukotoxin concentration, a large number of pores may kill the target cell predominantly by necrotic damage, however $S$. aureus leukocidins activate apoptotic cascades as well, therefore this type of $S$. aureus-induced cell death is a concerted mechanism [38, 29].

$$
H \lg A B / H \lg C B(\gamma \text {-hemolysin) }
$$

\section{Genetic organization}

The genes encoding $\gamma$-hemolysin (also known as $\mathrm{H} \operatorname{lgAB} / \mathrm{HlgCB}$ ), are present in $99.5 \%$ of human $S$. aureus isolates. The expression of these proteins is significantly upregulated during in vitro culturing with human blood and phagocytosis by neutrophils [39].

Bacterial genes are organized in operons where genes that are involved in similar processes or have complementary function are co-transcribed from the same promoter. Indeed, the genetic architecture of the genes hlgC and hlgB encoding HlgCB $\gamma$-hemolysin is represented by a classical operon organization and controlled by a single promoter [40-42]. On the other hand, the hlgA gene is located upstream of hlgC and $\mathrm{hlgB}$ and controlled by an individual promoter, making the entire organization of these three complementary genes an exception among leukocidins. It is important to note that all three genes $h \lg \mathrm{A}, \mathrm{hlgC}$ and $\mathrm{hlgB}$ are located in the core genome of S. aureus, unlike many other toxins that locate on extrachromosomal elements [41]. The expression of these genes leads to the formation of two S subunits, HlgA and HlgC, and one shared F subunit, HlgB [40]. This locus is highly conserved among S. aureus strains (99\% of all strains analyzed) $[43,44]$, however the degree of sequence homology differs between the different strains [43].

\section{Cellular specificity}

$\mathrm{Hlg} \mathrm{AB}$ and $\mathrm{HlgCB}$ act as classical leukocidins, forming pores on the surface of target cells which induce cell lysis. However, the formation of these pores depends on the initial binding of the leukocidins to chemokine receptors on the surface of phagocytic cells [39]. Currently, three receptors (CXCR1, CXCR2 and CCR2) have been identified as targets for HlgAB and two (C5aR and C5L2) as targets of HlgCB [39]. Phagocytes express the above-mentioned receptors at high level and are the major cellular target of HlgAB and $\mathrm{HlgCB}$, in contrast to other immune cell types that do not express those receptors or express them at lower level. Interestingly, in addition to the cytolytic function, $\mathrm{HlgAB}$ and $\mathrm{HlgCB}$ possess pro-inflammatory and immunomodulatory properties. Both toxin complexes act through the same receptors during priming and inflammasome activation [29, 39].

\section{$L u k A B / H G$}

\section{Genetic organization}

LukAB (also known as LukHG), is encoded by the core genome of $S$. aureus. The lukA and lukB genes have classical operon organization [29]. The level of conservation for these genes among different $S$. aureus 
strains has not been extensively characterized, however this operon is present in the majority of laboratory $S$. aureus isolates [28]. A certain degree of genetic diversity seem to exist in small subsets of the bacterial isolates, although the information available is scarce [29].

\section{Cellular specificity}

LukAB is one of the most recently identified leukotoxin and it is able to kill primary human neutrophils, monocytes, macrophages and dendritic cells [45]. The binding of LukAB to its target cell types is determined by the presence of CD11b, a component of the CD11b/CD18 integrin complex [46] that functions as a cell surface antigen, plays a critical role in leukocyte adhesion and is required for host defense [47]. The glutamic acid at position 323 of the C-terminal domain of LukA engages the I-domain of CD11b and this binding is an important prerequisite for pore formation and cell lysis [48]. LukAB production by S. aureus is also required for the escape from neutrophil induced phagocytosis, which indicates that this toxin is likely playing an important role in evading host defense and survival [46].

\section{LukED}

\section{Genetic organization}

LukED operon is located on a pathogenicity island found in the genome of $S$. aureus, known as vSa $\beta$. Pathogenicity islands are an example of extrachromosomal elements that possess different degree of stability. This genetic element is likely a result of phage integration into the host genome of $S$. aureus, which later underwent a number or recombination, as well as insertion/excision eventsand that now is considered to be stable [49]. This extrachromosomal element is the result of a horizontal gene transfer and integration into the $S$. aureus genome. It has been predicted to be present in only $70 \%$ of all isolated $S$. aureus strains [50, 44]. Its presence is strictly lineage dependent and some lineages do not have this gene. The lineages possessing this island demonstrate strong sequence conservation suggesting a common origin [50]. lukE and lukD represent a small fraction of the genes located on $\mathrm{vSa} \beta[49]$, among the other genes there are different virulence factors such as serine proteases, enterotoxins, bacteriocins and a hyaluronate lyase [49].

\section{Cellular specificity}

LukED is a well characterized leukocidin and it possesses lytic activity against leukocytes from several species, including human, murine, rabbit, canines and even fish [51-54]. LukED can target human macrophages, T-cells and dendritic cells via its binding to CCR5, which functions also as co-receptor for human immunodeficiency virus (HIV) [53]. LukE, the S subunit, is the ligand for CCR5-expressing cells. LukED mechanism of action satisfies previously proposed models where the $\mathrm{S}$ subunit initiates the binding and recruits the $\mathrm{F}$ subunit to proceed with pore formation [53,55]. In addition, it was shown that the FDA-approved CCR5 antagonist maraviroc can block the interaction between LukE and CCR5 [53], and recently developed potent CCL5 derivatives are presently being investigated in this context $[56,57]$. These data confirm the specificity of this interaction and proves that a drug currently used as HIV-1 inhibitor has repositioning potentials as a treatment option for S. aureus infections [53].

LukED can also kill polymorphonuclear leukocytes (PMNs) that do not express CCR5, indicating an additional mechanism of PMNs targeting $[51,52,58,59]$. This mechanism has been revealed, as two additional receptors, CXCR1 and CXCR2, expressed on the surface of primary human neutrophils, monocytes, natural killer (NK) cells, and a subset of $\mathrm{CD}^{+} \mathrm{T}$-cells cells, appear to be alternative binding partners for LukED [59]. In an elegant set of experiments, it was demonstrated that only LukE, but not LukD is able to specifically bind to CXCR1 and CXCR2 in a similar manner to CCR5. The LukED binding to PMNs increases the pathogenesis and immune escape capabilities of $S$. aureus [59]. LukED binding to CCR5 positive cells eliminates T-cells (such as memory and Th1/Th17 cells) and antigen presenting cell. On the other hand, LukED binding to CXCR1 and CXCR2 eliminates PMNs, monocytes, and NK cells [59]. Thus, by the recognition of specific receptors on particular cell subsets via LukED, S. aureus is able to target the adaptive and innate branches of our immune system, making this pathogen highly efficient at avoiding the immune system response of humans and other vertebrates.

\section{Panton-Valentine leukocidin (PVL)}

\section{Genetic organization}

PVL is one of the most characterized $S$. aureus leukocidins. It was originally purified by Woodin in the 1960s and since then it has been extensively studied [60, 61]. PVL toxin formation requires the expression of two genes, $l u k S-P V$ and $l u k F-P V$, located on the prophage $\phi S \mathrm{Sa}$. Unlike other leukocidins, that are stably 
associated with the $S$. aureus chromosome, $\phi \mathrm{Sa} 2$ can be transmitted vertically and horizontally during the lysogenic and lytic cycles respectively [62]. This is a classical example of mobile genetic element that can increase the genetic diversity for this particular locus and its associated genes, and lead to the acquisition of new virulence factors by $S$. aureus. PVLis present in a rather limited number of $S$. aureus isolates $(2-3 \%$ of the total) [63]. However, in pathogenic strains including CA-MRSA and strains causing severe necrotizing pneumonia the percentage of the isolates carrying PVL has an extremely high frequency, reaching up to $90 \%$ [64-67]. Therefore, it seems likely that enhanced virulence of community-acquired infections is partly associated with the $\phi \mathrm{Sa} 2$ phage acquisition, although pathogenicity of these strains is not connected to the presence of PVL leukocidin only, and the extent of its influence is yet to be identified [68].

\section{Cellular specificity}

PVL has more than $75 \%$ sequence identity to the LukED, however the two leukocidins do not target the same cellular receptors (28). This is likely due to the significant sequence diversity in the rim domains of PVL and LukED. The rim domain is responsible for receptor recognition, and PVL has a reduced range of cell targets in comparison to $\operatorname{LukED}(59,69-71)$.

PVL, similarly to other leukocidins, forms an octameric pore consisting of LukS-PV and LukF-PV subunits on the surface of myeloid cells, in particular granulocytes and macrophages of different animal species and humans; toxin pores lead to cell lysis [72]. Interestingly, in rabbits and mice, PVL is not lethal albeit it can cause transient granulocytopenia followed by marked granulocytosis [73, 74]. Sub-lytic PVL concentration causes human neutrophil to undergo apoptosis within six hours, while higher concentrations cause cell lysis in one hour [75].

A report by Spaan et al. suggests that the LukS-PV subunit is able to displace a fluorescently-labeled antibodies from two leukocyte cell surface receptors (C5aR and C5L2) [76]. This was the first demonstration of PVL cellular specificity in which the toxin was able to bind the receptor core, membrane spanning portions as well as the extracellular N-terminal region. Interestingly, CXCR2 which, in addition to CCR5, serves as LukE receptor, was used as a negative control. Indeed, it was shown that PVL was not able to bind to the cell surface of cells expressing CXCR2 [76]. These findings confirm the idea that LukE and PVL do not share the same receptors, regardless of their significant sequence conservation [76, 59].

\section{LukMF}

\section{Genetic organization}

LukMF is the most recently identified leukocidine, predominantly found in strains isolated from bovine mastitis [77]. It is encoded by the temperate phage $\varphi S a 1$, which can be transmitted vertically and horizontally during both the lysogenic and lytic cycles [78, 79]. The frequency of LukMF in strains isolated from bovine infections varies significantly (from as low as $10 \%$ to as high as $90 \%$ ), depending on the site of isolation and geographic origin of the strains $[68,78,80,81]$. It is important to mention that cattle mastitis is associated with the presence of LukMF genes in the $S$. aureus strains producing infection [81]. Other cell types affected by LukMF include bovine monocytes and macrophages, but not B cells [82].

A report by Vrieling et al. shed light onto the mechanisms of LukMF cell targeting, with the identification of CCR1 as the main receptor [83]. CCR1 is abundantly expressed on bovine neutrophils, the main cell type preventing intramammary inflammation [84]. It has also been demonstrated that the divergent region 4 (DR4) of LukM is required for the specific binding to the extra-cellular loop 2 (ECL2) and extra-cellular loop 3 (ECL3) of CCR1. In addition, several amino acid residues of CCR1 ECL2 have also been identified to contribute to LukM binding, including E177, F178 and H181, while the entire ECL3 has been shown to be essential for toxin binding [83]. Interestingly, DR4 has also been identified in LukE to be required for CCR5 recognition [59]. The overall homology between LukE and LukM is 77,5\% [29]. This data provides an in depth understanding of the molecular interaction between the LukM and CCR1, expressed on the surface of bovine neutrophils.

In addition to CCR1, the most prominent target of LukMF, two other receptors have been identified as targets of LukMF (CCR2 and CCR5) [83]. It has been shown that the presence of LukMF in the culture supernatant was sufficient to kill CCR2 and CCR5 expressing cells, likely leading to the elimination of subsets of T-cells, inflammatory macrophages and dendritic cells. Unfortunately, the receptor moieties critical for the interaction with LukMF have not been identified yet. 


\section{Conclusion}

In this review we described the current understanding of the genetic organization and molecular interaction of $S$. aureus leukocidins with human cells. Leukocidins play an important role in bacterial pathogenesis and represent a significant healthcare burden. Understanding the genetic organization, sequence similarity and location of $S$. aureus leukocidin encoding genes can help us improve diagnostic methods educating more personalized antibacterial treatments. Furthermore, improved understanding of the molecular interactions between $S$. aureus leukocidins and human cell surface receptors may lead to the development of alternative antimicrobial agents that, either independently or in combination with currently used antibiotics, may provide new effective weapons in the combat of antibiotic resistance.

This research was funded by the Science Committee of the Ministry of Education and Science of the Republic of Kazakhstan (Grant No. AP05134810).

\section{References}

1 Kirby, W.M. (1944). Extraction of a highly potent penicillin resistant Staphylococci. Science, 99(2579), 452-453. DOI: 10.1126/science.99.2579.452

2 Rountree, P.M., \& Freeeman, B.M. (1955). Infections caused by a particular phage type of Staphylococcus aureus. Med. J. Aust., 42(5), 157-161.

3 Jevons, M.P., \& Parker, M.T. (1964) The Evolution of the New Hospital Strains of Staphylococcus Aureus. J. Clin. Pathol. 17(3), 243-250. DOI: 10.1136/jcp.17.3.243

4 Klevens, R.M., Edwards, J.R., \& Tenover, F.C., et al. (2006). Changes in the epidemiology of methicillin-resistant Staphylococcus aureus in intensive care units in US hospitals, 1992-2003. Clin Infect Dis, 42(3), 389-391. DOI: 10.1086/499367

5 Klein, E., Smith, D.L., \& Laxminarayan, R. (2007). Hospitalizations and deaths caused by methicillin-resistant Staphylococcus aureus, United States, 1999-2005. Emerg Infect Dis. 13(12), 1840-1846. DOI: 10.3201/eid1312.070629

6 Klevens, R.M., Morrison, M.A, \& Nadle, J. et al. (2007). Invasive methicillin-resistant Staphylococcus aureus infections in the United States. JAMA, 298(15), 1763-1771. DOI: 10.1001/jama.298.15.1763

7 https://www.cdc.gov/nchs/data/nvsr/nvsr56/nvsr56_16.pdf

8 Vandenesch, F., Naimi, T., \& Enright, M.C., et al. (2003). Community-acquired methicillin-resistant Staphylococcus aureus carrying Panton-Valentine leukocidin genes: worldwide emergence. Emerg Infect Dis, 9(8), 978-984. DOI: 10.3201/eid0908.030089

9 Chambers, H.F. (2001) The changing epidemiology of Staphylococcus aureus? Emerg Infect Dis, 7(2), 178-182. DOI: 10.3201/eid0702.010204

10 Kaplan, S.L., Hulten, K.G., \& Gonzalez, B.E. et al. (2005). Three-year surveillance of community-acquired Staphylococcus aureus infections in children. Clin Infect Dis, 40(12), 1785-1791 DOI: 10.1086/430312

$11 \mathrm{https} / /$ www.cdc.gov/niosh/topics/mrsa/default.html

12 DeLeo, F.R., Otto, M., Kreiswirth, B.N., \& Chambers, H.F. (2010). Community-associated meticillin-resistant Staphylococcus aureus. Lancet, 375(9725), 1557-1568. DOI: 10.1016/S0140-6736(09)61999-1

13 Hawkins, C., Huang, J., Jin, N., Noskin, G.A., Zembower, T.R., \& Bolon, M. (2007). Persistent Staphylococcus aureus bacteremia: an analysis of risk factors and outcomes. Arch Intern Med, 167(17), 1861-1867. DOI: 10.1001/archinte.167.17.1861

14 Dombrowski, J.C., \& Winston, L.G. (2008). Clinical failures of appropriately-treated methicillin-resistant Staphylococcus aureus infections. $J$ Infect, 57(2), 110-115. doi: 10.1016/j.jinf.2008.04.003

15 Lodise, T.P., Lomaestro, B., Graves J., \& Drusano, G.L. (2008). Larger vancomycin doses (at least four grams per day) are associated with an increased incidence of nephrotoxicity. Antimicrob Agents Chemother, 52(4), 1330-1336. DOI: 10.1128/AAC.01602-07

16 Howe, R.A., Monk, A., Wootton, M., Walsh, T.R., \& Enright, M.C. (2004). Vancomycin susceptibility within methicillinresistant Staphylococcus aureus lineages. Emerg Infect Dis, 10(5), 855-857. DOI: 10.3201/eid1005.030556

17 Kuroda, M., Ohta, T., Uchiyama, I., et al. (2001). Whole genome sequencing of meticillin-resistant Staphylococcus aureus. Lancet, 357(9264), 1225-1240. DOI: 10.1016/s0140-6736(00)04403-2

18 DeLeo, F.R., \& Chambers, H.F. (2009). Reemergence of antibiotic-resistant Staphylococcus aureus in the genomics era. J Clin Invest; 119(9), 2464-2474. DOI: 10.1172/JCI38226

19 Rogers, D.E., \& Tompsett, R. (1952). The survival of staphylococci within human leukocytes. J Exp Med, 95(2), $209-230$. DOI: $10.1084 /$ jem.95.2.209

20 Voyich, J.M., Braughton, K.R., \& Sturdevant, D.E., et al. (2005). Insights into mechanisms used by Staphylococcus aureus to avoid destruction by human neutrophils. J Immunol, 175(6), 3907-3919. DOI: 10.4049/jimmunol.175.6.3907

21 Malachowa, N., DeLeo, F.R. (2010). Mobile genetic elements of Staphylococcus aureus. Cell Mol Life Sci, 67(18), 30573071. DOI: 10.1007/s00018-010-0389-4

22 Baba, T., Bae, T., Schneewind, O., Takeuchi, F., \& Hiramatsu, K. (2008). Genome sequence of Staphylococcus aureus strain Newman and comparative analysis of staphylococcal genomes: polymorphism and evolution of two major pathogenicity islands. J Bacteriol, 190(1), 300-310. DOI: 10.1128/JB.01000-07

23 Fitzgerald, J.R., Monday, S.R., \& Foster, T.J. et al. (2001). Characterization of a putative pathogenicity island from bovine Staphylococcus aureus encoding multiple superantigens. J Bacteriol, 183(1), 63-70. DOI: 10.1128/JB.183.1.63-70.2001 
24 Lindsay, J.A., \& Holden, M.T. (2004). Staphylococcus aureus: superbug, super genome? Trends Microbiol, 12(8), $378-385$. DOI: 10.1016/j.tim.2004.06.004

25 Vandenesch, F, Lina, G, \& Henry, T. (2012). Staphylococcus aureus hemolysins, bi-component leukocidins, and cytolytic peptides: a redundant arsenal of membrane-damaging virulence factors? Front Cell Infect Microbiol, 2, 12 . DOI: $10.3389 /$ fcimb. 2012.00012

26 Alonzo, F $3^{\text {rd }}$, \& Torres, V.J. (2013). Bacterial survival amidst an immune onslaught: the contribution of the Staphylococcus aureus leukotoxins. PLoS Pathog, 9(2), e1003143. DOI: 10.1371/journal.ppat.1003143

27 Foster, T.J. (2004). The Staphylococcus aureus «superbug». J Clin Invest, 114(12), 1693-1696. DOI: 10.1172/JCI23825

28 Yoong P., \& Torres V.J. (2013). The effects of Staphylococcus aureus leukotoxins on the host: cell lysis and beyond. Curr Opin Microbiol, 16(1), 63-69. DOI: 10.1016/j.mib.2013.01.012

29 Alonzo, F 3rd, \& Torres, V.J. (2014). The bicomponent pore-forming leucocidins of Staphylococcus aureus. Microbiol Mol Biol Rev, 78(2), 199-230. DOI: 10.1128/MMBR.00055-13

30 Bagnoli, F., Bertholet, S., \& Grandi, G. (2012). Inferring reasons for the failure of Staphylococcus aureus vaccines in clinical trials. Front Cell Infect Microbiol., 2, 16. DOI: 10.3389/fcimb.2012.00016

31 Proctor, R.A. (2012). Challenges for a universal Staphylococcus aureus vaccine. Clin Infect Dis, 54(8), 1179-1186. DOI: $10.1093 / \mathrm{cid} / \mathrm{cis} 033$

32 Otto, M. (2010). Novel targeted immunotherapy approaches for staphylococcal infection. Expert Opin Biol Ther, 10(7), 1049-1059. DOI: $10.1517 / 14712598.2010 .495115$

33 Vandenesch, F., Lina, G., \& Henry, T. (2012). Staphylococcus aureus hemolysins, bi-component leukocidins, and cytolytic peptides: a redundant arsenal of membrane-damaging virulence factors? Front Cell Infect Microbiol, 2, 12. DOI: $10.3389 /$ fcimb. 2012.00012

34 Rogolsky, M. (1979). Nonenteric toxins of Staphylococcus aureus. Microbiol Rev, 43(3), 320-360.

35 Ozawa, T., Kaneko, J., \& Kamio, Y. (1995). Essential binding of LukF of staphylococcal gamma-hemolysin followed by the binding of $\mathrm{H}$ gamma II for the hemolysis of human erythrocytes. Biosci Biotechnol Biochem, 59(6), 1181-1183. DOI: $10.1271 / \mathrm{bbb} .59 .1181$

36 Yokota, K., \& Kamio, Y. (2000). Tyrosine72 residue at the bottom of rim domain in LukF crucial for the sequential binding of the staphylococcal gamma-hemolysin to human erythrocytes. Biosci Biotechnol Biochem, 64(12), 2744-2747. DOI: $10.1271 / \mathrm{bbb} .64 .2744$

37 Aman, M.J, Karauzum, H., Bowden, M.G., \& Nguyen, T.L. (2010). Structural model of the pre-pore ring-like structure of Panton-Valentine leukocidin: providing dimensionality to biophysical and mutational data. J Biomol Struct Dyn, 28(1), 1-12. DOI: $10.1080 / 073911010010524952$

38 Genestier, A.L., Michallet, M.C., \& Prévost, G. et al. (2005). Staphylococcus aureus Panton-Valentine leukocidin directly targets mitochondria and induces Bax-independent apoptosis of human neutrophils. J Clin Invest, 115(11), 3117-3127. DOI: $10.1172 / \mathrm{JCI} 22684$

39 Spaan, A.N., Vrieling, M., \& Wallet, P. et al. (2014). The staphylococcal toxins $\gamma$-haemolysin AB and CB differentially target phagocytes by employing specific chemokine receptors. Nat Commun, 5, 5438. DOI: 10.1038/ncomms6438

40 Cooney, J., Kienle, Z., Foster, T.J., \& O'Toole, P.W. (1993). The gamma-hemolysin locus of Staphylococcus aureus comprises three linked genes, two of which are identical to the genes for the $\mathrm{F}$ and S components of leukocidin. Infect Immun, 61(2), $768-771$.

41 Cooney, J., Mulvey, M., Arbuthnott, J.P., \& Foster, T.J. (1988). Molecular cloning and genetic analysis of the determinant for gamma-lysin, a two-component toxin of Staphylococcus aureus. J Gen Microbiol, 134(8), 2179-2188. DOI: 10.1099/00221287$134-8-2179$

42 Prévost, G., Cribier, B., \& Couppié, P. et al. (1995). Panton-Valentine leucocidin and gamma-hemolysin from Staphylococcus aureus ATCC 49775 are encoded by distinct genetic loci and have different biological activities. Infect Immun, 63(10), 41214129 .

43 McCarthy, A.J., \& Lindsay, J.A. Staphylococcus aureus innate immune evasion is lineage-specific: a bioinfomatics study. Infect Genet Evol, 19, 7-14. DOI: 10.1016/j.meegid.2013.06.012

44 von Eiff, C., Friedrich, A.W, Peters, G., \& Becker K. (2004). Prevalence of genes encoding for members of the staphylococcal leukotoxin family among clinical isolates of Staphylococcus aureus. Diagn Microbiol Infect Dis, 49(3), 157-162. DOI: 10.1016/j.diagmicrobio.2004.03.009

45 Dumont, A.L., Nygaard, T.K., \& Watkins, R.L. et al. (2011). Characterization of a new cytotoxin that contributes to Staphylococcus aureus pathogenesis. Mol Microbiol, 79(3), 814-825. DOI: 10.1111/j.1365-2958.2010.07490.x

46 DuMont, A.L, Yoong, P., \& Day, C.J. et al. (2013). Staphylococcus aureus LukAB cytotoxin kills human neutrophils by targeting the CD11b subunit of the integrin Mac-1. Proc Natl Acad Sci U S A, 110(26), 10794-10799. DOI: 10.1073/pnas.1305121110

47 Mazzone, A., \& Ricevuti, G. (1995). Leukocyte CD11/CD18 integrins: biological and clinical relevance. Haematologica, $80(2), 161-175$.

48 DuMont, A.L., Yoong, P., \& Liu, X., et al. (2014). Identification of a crucial residue required for Staphylococcus aureus LukAB cytotoxicity and receptor recognition. Infect Immun, 82(3), 1268-1276. DOI: 10.1128/IAI.01444-13

49 Kläui, A.J., Boss, R., \& Graber, H.U. (2019). Characterization and Comparative Analysis of the Staphylococcus aureus Genomic Island vSaß: an In Silico Approach. J Bacteriol, 201(22), e00777-18. DOI: 10.1128/JB.00777-18

50 McCarthy, A.J., \& Lindsay, J.A. (2013). Staphylococcus aureus innate immune evasion is lineage-specific: a bioinfomatics study. Infect Genet Evol, 19, 7-14. DOI:10.1016/j.meegid.2013.06.012

51 Alonzo, F $3^{\text {rd }}$., Benson, M.A., Chen, J., Novick, R.P., Shopsin, B., \& Torres, V.J. (2012). Staphylococcus aureus leucocidin ED contributes to systemic infection by targeting neutrophils and promoting bacterial growth in vivo. Mol Microbiol, 83(2), 423435. DOI: $10.1111 / j .1365-2958.2011 .07942 . x$ 
52 Morinaga, N., Kaihou, Y., \& Noda, M. (2003). Purification, cloning and characterization of variant LukE-LukD with strong leukocidal activity of staphylococcal bi-component leukotoxin family. Microbiol Immunol, 47(1), 81-90. DOI: 10.1111/j.13480421.2003.tb02789.x

53 Alonzo, F $3^{\text {rd }}$, Kozhaya, L., \& Rawlings, S.A., et al. (2013). CCR5 is a receptor for Staphylococcus aureus leukotoxin ED. Nature, 493(7430), 51-55. DOI: 10.1038/nature11724

54 Bownik, A. (2006). In vitro effects of staphylococcal leukocidin LukE/LukD on the proliferative ability of lymphocytes isolated from common carp (Cyprinus carpio L.). Fish Shellfish Immunol, 20(4), 656-659. DOI: 10.1016/j.fsi.2005.07.002

55 Colin, D.A., Mazurier, I., Sire, S., \& Finck-Barbançon, V. (1994). Interaction of the two components of leukocidin from Staphylococcus aureus with human polymorphonuclear leukocyte membranes: sequential binding and subsequent activation. Infect Immun, 62(8), 3184-3188.

56 Vangelista, L., \& Vento, S. (2018). The Expanding Therapeutic Perspective of CCR5 Blockade. Front Immunol, 8, 1981. DOI: $10.3389 /$ fimmu.2017.01981

57 Secchi, M., Grampa, V., \& Vangelista, L. (2018). Rational CCL5 mutagenesis integration in a lactobacilli platform generates extremely potent HIV-1 blockers. Sci Rep, 8, 1890. DOI: 10.1038/s41598-018-20300-9

58 Gravet, A., Colin, D.A., Keller, D., Girardot, R., Monteil, H., \& Prévost, G. (1998). Characterization of a novel structural member, LukE-LukD, of the bi-component staphylococcal leucotoxins family. FEBS Lett, 436(2), 202-208. DOI: 10.1016/s00145793(98)01130-2

59 Reyes-Robles, T., Alonzo, F 3rd, Kozhaya, L., Lacy, D.B., Unutmaz, D., \& Torres, V.J. (2013). Staphylococcus aureus leukotoxin ED targets the chemokine receptors CXCR1 and CXCR2 to kill leukocytes and promote infection. Cell Host Microbe, 14(4), 453-459. DOI: 10.1016/j.chom.2013.09.005

60 Tromp, A.T., van Strijp, J.A.G. (2020). Studying Staphylococcal Leukocidins: A Challenging Endeavor. Front Microbiol, 11, 611. DOI: $10.3389 /$ fmicb.2020.00611

61 Woodin, A.M. (1959). Fractionation of a leucocidin from Staphylococcus aureus. Biochem J, 73(2), 225-237. DOI: $10.1042 / \mathrm{bj} 0730225$

62 Hatfull, G.F., \& Hendrix, R.W. (2011). Bacteriophages and their genomes. Curr Opin Virol, 1(4), 298-303. DOI: 10.1016/j.coviro.2011.06.009

63 Kuehnert, M.J., Kruszon-Moran, D., \& Hill, H.A. et al. (2006). Prevalence of Staphylococcus aureus nasal colonization in the United States, 2001-2002. J Infect Dis, 193(2), 172-179. DOI: 10.1086/499632

64 Lina, G., Piémont, Y., \& Godail-Gamot, F., et al. (1999). Involvement of Panton-Valentine leukocidin-producing Staphylococcus aureus in primary skin infections and pneumonia. Clin Infect Dis, 29(5), 1128-1132. DOI: 10.1086/313461

65 Gillet, Y., Issartel, B., \& Vanhems, P., et al. (2002). Association between Staphylococcus aureus strains carrying gene for Panton-Valentine leukocidin and highly lethal necrotising pneumonia in young immunocompetent patients. Lancet, 359(9308), 753759. DOI: $10.1016 / \mathrm{S} 0140-6736(02) 07877-7$

66 Naimi, T.S., LeDell, K.H., \& Como-Sabetti, K., et al. (2003). Comparison of community- and health care-associated methicillin-resistant Staphylococcus aureus infection. JAMA, 290(22), 2976-2984. DOI: 10.1001/jama.290.22.2976

67 Shallcross, L.J., Fragaszy, E, Johnson, A.M., \& Hayward, A.C. (2013). The role of the Panton-Valentine leucocidin toxin in staphylococcal disease: a systematic review and meta-analysis. Lancet Infect Dis, 13(1), 43-54. DOI: 10.1016/S14733099(12)70238-4

68 Rainard, P., Corrales, J.C., Barrio, M.B., Cochard, T., \& Poutrel, B. (2003). Leucotoxic activities of Staphylococcus aureus strains isolated from cows, ewes, and goats with mastitis: importance of LukM/LukF'-PV leukotoxin. Clin Diagn Lab Immunol, 10(2), 272-277. DOI: $10.1128 /$ cdli.10.2.272-277.2003

69 Meunier, O., Falkenrodt, A., Monteil, H., \& Colin, D.A. (1995). Application of flow cytometry in toxinology: pathophysiology of human polymorphonuclear leukocytes damaged by a pore-forming toxin from Staphylococcus aureus. Cytometry, 21(3), 241247. DOI: $10.1002 /$ cyto.990210304

70 Gauduchon, V., Werner, S., Prévost, G., Monteil, H., \& Colin, D.A. (2001). Flow cytometric determination of PantonValentine leucocidin S component binding. Infect Immun, 69(4), 2390-2395. DOI: 10.1128/IAI.69.4.2390-2395.2001

71 Löffler, B., Hussain, M., \& Grundmeier, M. et al. (2010) Staphylococcus aureus panton-valentine leukocidin is a very potent cytotoxic factor for human neutrophils. PLoS Pathog, 6(1), e1000715. DOI: 10.1371/journal.ppat.1000715

72 Jayasinghe, L., \& Bayley, H. (2005). The leukocidin pore: evidence for an octamer with four LukF subunits and four LukS subunits alternating around a central axis. Protein Sci, 14(10), 2550-2561. DOI: 10.1110/ps.051648505

73 Szmigielski, S., Jeljaszewicz, J., Wilczynski, J., \& Korbecki, M. (1966). Reaction of rabbit leucocytes to staphylococcal (Panton-Valentine) leucocidin in vivo. J Pathol Bacteriol, 91(2), 599-604. DOI: 10.1002/path.1700910237

74 Grójec, P.L., \& Jeljaszewicz, J. (1981). Effect of staphylococcal leukocidin on mouse leukocyte system. Bakteriol Mikrobiol Hyg A, 250(4), 446-455.

75 Genestier, A.L., Michallet, M.C., \& Prévost G., et al. (2005). Staphylococcus aureus Panton-Valentine leukocidin directly targets mitochondria and induces Bax-independent apoptosis of human neutrophils. J Clin Invest, 115(11), 3117-3127. DOI: $10.1172 /$ JCI22684

76 Spaan, A.N., Henry, T., \& van Rooijen, W.J.M., et al. (2013). The staphylococcal toxin Panton-Valentine Leukocidin targets human C5a receptors. Cell Host Microbe, 13(5), 584-594. DOI: 10.1016/j.chom.2013.04.006

77 Barrio, M.B., Rainard, P., \& Prévost, G. (2006). LukM/LukF'-PV is the most active Staphylococcus aureus leukotoxin on bovine neutrophils. Microbes Infect, 8(8), 2068-2074. DOI: 10.1016/j.micinf.2006.03.004

78 Yamada, T., Tochimaru, N., \& Nakasuji, S., et al. (2005). Leukotoxin family genes in Staphylococcus aureus isolated from domestic animals and prevalence of lukM-lukF-PV genes by bacteriophages in bovine isolates. Vet Microbiol, 110(1-2), 97-103. DOI: $10.1016 /$ j.vetmic.2005.07.006 
79 Zou, D., Kaneko, J., Narita, S., Kamio, Y. (2000). Prophage, phiPV83-pro, carrying panton-valentine leukocidin genes, on the Staphylococcus aureus P83 chromosome: comparative analysis of the genome structures of phiPV83-pro, phiPVL, phi11, and other phages. Biosci Biotechnol Biochem, 64(12), 2631-2643. DOI: 10.1271/bbb.64.2631

80 Padmaja, R.J., \& Halami, P.M. (2013). Molecular Characterization and Toxicity Confirmation of LukM/F'-PV Producing Staphylococcus aureus Isolated from Bovine Mastitis Samples in Mysore, India. Indian J Microbiol, 53(3), 276-282. DOI: 10.1007/s12088-013-0359-2

81 Monecke, S., Kuhnert, P., Hotzel, H., Slickers, P., \& Ehricht, R. (2007). Microarray based study on virulence-associated genes and resistance determinants of Staphylococcus aureus isolates from cattle. Vet Microbiol, 125(1-2), 128-140. DOI: 10.1016/j.vetmic.2007.05.016

82 Fromageau, A., Gilbert, F.B., Prévost, G., \& Rainard, P. (2010). Binding of the Staphylococcus aureus leucotoxin LukM to its leucocyte targets. Microb Pathog, 49(6), 354-362. DOI: 10.1016/j.micpath.2010.07.002

83 Vrieling, M., Koymans., K.J., \& Heesterbeek, D.A., et al. (2015). Bovine Staphylococcus aureus Secretes the Leukocidin LukMF' To Kill Migrating Neutrophils through CCR1. mBio, 6(3), e00335. DOI: 10.1128/mBio.00335-15

84 Rainard, P., \& Riollet, C. (2003). Mobilization of neutrophils and defense of the bovine mammary gland. ReprodNutr Dev, 43(5), 439-457. DOI: $10.1051 /$ rnd:2003031

\title{
Д. Буланин, Е.А. Марченко, Г.К. Абитаева, Л. Вангелиста \\ S. aureus лейкоцидиндердің генетикалық ұйымы және жасушалық ерекшелігі
}

\begin{abstract}
Қазіргі уақытта S. aureus грамоң бактерия тудыратын инфекциялар бүкіләлемдегі денсаулық сақтау үшін ауыртпалық болып табылады. Бұл бактериялардың антибиотиктерге қарсы тұрақтылықты қалыптастыру және адамның иммундық реакциясынан тиімді түрде жалтару қабілетіне байланысты. Сондықтан әлемдегі көптеген ғылыми зертханалардың зерттеу жұмыстары генетикалық ұйымды және $S$. aureus патогенезіне жауап беретін молекулалық механизмдерді сипаттауға бағытталған. Бұл шолуда бактериялық патогенезінде маңызды рөл атқаратын және денсаулық сақтау үшін ауыртпалық тудыратын S. aureus лейкоцидиндерінің адам жасушаларымен генетикалық ұйымы және молекулалық өзара әрекеттесуі туралы түсінігімізге байланысты өсіп жатқан дәлелдемелер жиынтығы сипатталған. Уытты қасиеттердің асырылуына жауап беретін қосымша механизмдермен байланысты генетикалық ұйым түсінігі бізге S. aureus инфекцияларына қарсы жеке терапияны дамытуға көмектеседі. Осылайша, S. aureus лейкоцидиндерімен жасуша бетіндегі рецепторлар арасындағы молекулалық өзара әрекеттесуді жақсырақ түсіну микробқақарсы баламалы агенттердің дамуына әкелуі мүмкін. Оларды өздігінен немесе қолданыстағы антибиотикалық емдеу режимдерімен бірге тиімді емдеу стратегиясы ретінде қолданады.
\end{abstract}

Kiлm cөздеp: Staphylococcus aureus, генетикалық ұйымы, лейкоцидиндер, бактериялық инфекция, токсиндер, изоляттар.

\section{Д. Буланин, Е.А. Марченко, Г.К. Абитаева, Л. Вангелиста \\ Генетическая организация и клеточная специфичность лейкоцидинов $S$. aureus}

В настоящее время инфекции, вызываемые грамположительными бактериями $S$. aureus, представляют собой серьезную проблему для здравоохранения во всем мире. Это объясняется способностью этих бактерий развивать устойчивость к антибиотикам и эффективно уклоняться от иммунного ответа человека. Таким образом, исследовательские усилия многих научных лабораторий по всему миру направлены на определение генетической организации и молекулярных механизмов, ответственных за патогенез S. aureus. Данное сообщение описывает растущий объем доказательств, связанных с нашим пониманием генетической организации и молекулярных взаимодействий лейкоцидинов $S$. aureus c клетками человека, которые играют важную роль в бактериальном патогенезе и представляют собой значительную нагрузку на здравоохранение. Понимание генетической организации, связанной с дополнительными механизмами, ответственными за реализацию токсического потенциала, может помочь нам разработать более персонализированный подход к терапии против инфекций S. aureus. Taким образом, улучшенное понимание молекулярных взаимодействий между лейкоцидинами $S$. aureus и рецепторами клеточной поверхности может привести к разработке альтернативных антимикробных агентов, которые либо независимо, либо в сочетании с текущими схемами лечения антибиотиками будут использоваться в качестве стратегий эффективного лечения в клинике.

Ключевые слова: Staphylococcus aureus, генетическая организация, лейкоцидины, бактериальная инфекция, токсины, изоляты. 